\title{
Ethnic hierarchy and public attitudes towards immigrants in Russia
}

\author{
Alexey Bessudnov \\ (University of Exeter, a.bessudnov@exeter.ac.uk)
}

December 2015

This is a pre-copyedited, author-produced PDF of an article accepted for publication in the European Sociological Review. The version of record (published online on 13 February 2016, DOI: 10.1093/esr/jcw002) is available online at: http://esr.oxfordjournals.org/content/early/ 2016/02/12/esr.jcw002. 


\begin{abstract}
Explanations of anti-immigrant attitudes in Europe have been centred around the labour market competition and group threat theories. The paper tests these theories with the data from Russia and finds some support for the group threat theory. Attitudes towards several immigrant ethnic groups are analysed separately. While Russians generally accept Ukrainians and Moldovans as their potential neighbours, they are more hostile to immigrants from the Caucasus and Central Asia. This ethnic hierarchy is shared by all large ethnic groups populating Russia. The analysis of regional level covariates of anti-immigrant sentiment shows that higher concentration of immigrants is associated with more negative attitudes towards most immigrant groups, except Ukrainians. Poorer regions are more xenophobic. The predictive power of statistical models explaining anti-immigrant prejudice is considerably lower in Russia compared to Western European countries. The paper discusses to what extent standard explanations of anti-immigrant attitudes in Europe can be applied in Russia.
\end{abstract}


A large inflow of immigrants to Western Europe and the USA in the last decade raises a question about the association between the size of the immigrant population and anti-immigrant attitudes. The group threat theory predicts that the increase in the number of immigrants may lead to more xenophobia. Empirical studies conducted in Europe so far produced contradictory results. Most studies found that there is a positive correlation between immigrant population size and anti-immigrant attitudes, but some studies did not detect any effects. There is an increasing understanding in the literature that attitudes to immigrants from different regions vary and some immigrant groups may trigger negative reactions of the natives to a larger extent than others.

In this paper we explore these ideas looking at the attitudes towards immigrants in Russia. Despite having one of the largest immigrant populations in the world, Russia has rarely been in the focus when it comes to studies of attitudes to immigrants. We use a survey of 24,500 individuals conducted in 2011 to investigate whether anti-immigrant attitudes in Russia can be better explained by economic competition at the individual level or the group threat theory. The sample size and design of the survey allow us to compare attitudes towards immigrants across Russian regions and identify regional level correlates of xenophobic attitudes. This analysis contributes to testing the group threat theory and to the discussion of macro-level contextual determinants of anti-immigrant prejudice. In addition, the paper presents an analysis of the attitudes towards different immigrant ethnic groups and explores an ethnic hierarchy in the attitudes towards immigrants. 
The group threat theory receives some support from the data. Attitudes towards immigrants in regions with a higher immigrant concentration are more negative. At the same time, poorer regions are also more xenophobic. Not all immigrants are equally unwelcome. Ukrainians and Moldovans are more acceptable to Russians than immigrants from the Caucasus and Central Asia. Interestingly, this perceived ethnic hierarchy is shared by all large ethnic groups populating Russia.

The paper is structured as follows. Section 1 provides a review of the main theories that explain anti-immigrant attitudes and formulates research questions. Section 2 presents main facts about international migration in Russia and reviews previous studies of anti-immigrant attitudes in this country. Section 4 discusses the data and modelling strategy, section 5 presents results of the analysis and section 6 discusses the findings.

\section{Determinants of the attitudes to immigrants. Research questions}

One of the central theoretical questions in the study of anti-immigrant attitudes is whether they can be better explained by individuals' economic circumstances or concerns about cultural and economic effects of immigration at the group level. Two main theories have been proposed. According to the labour market competition theory, immigrants may constitute an economic threat to native workers, especially in low paid unskilled occupations. Since the reservation wage of many immigrants is lower than for natives they may push local workers out of the labour 
market and increase unemployment. This also intensifies competition over housing. In response, natives may form negative attitudes about immigrants and immigration (see, for example, Mayda, 2006). According to this theory, individuals form their attitudes on the basis of their personal economic interests.

The group threat theory suggests that negative views about immigrants are mostly driven by concerns about the effect of immigration on society at large (see a review in Ceobanu and Escandell, 2010). These concerns may be cultural (such as the fear of losing natives' collective identity) or economic (such as worries about the fiscal contribution of immigrants). Thus, people may perceive immigrants as a threat irrespective of their personal economic status.

Most research conducted to date suggests that the perceived cultural and economic threat at the societal level is more important for determining attitudes towards immigrants than personal economic circumstances (Hainmueller and Hopkins, 2014). Hainmueller and Hiscox (2007) showed that individual cultural values and beliefs explained attitudes towards immigrants better than economic concerns. Dustmann and Preston (2007) demonstrated that for the British public, welfare and cultural concerns about immigration outweighed concerns related to the labour market competition.

One of the ways to test the economic competition theory empirically is simply to look at the individual level correlates of attitudes towards immigrants. If people's attitudes are driven by their personal economic circumstances we may expect the unemployed and members of occu- 
pations where competition with the immigrants is stronger to be more xenophobic. To test the group threat theory researchers usually looked at the macro-level correlates of anti-immigrant views, often with data from the European Social Survey (ESS), the Eurobarometer, and other cross-national surveys. We may expect that a higher concentration of immigrants will activate the group threat mechanism and will be associated with more negative attitudes. Economic conditions may also be important if group threat is mostly perceived as related to the economy: in countries with lower incomes and higher unemployment the impact of immigration may be viewed as mostly negative.

A number of studies, starting with the pioneering work by Quillian (1995), empirically assessed the association between the proportion of immigrants in the population and anti-immigrant views. In European countries with more immigrants attitudes towards them were generally more negative (Meuleman et al., 2009; Scheepers et al., 2002; Semyonov et al., 2006, 2008; Schneider, 2008). However, most studies were crosssectional and it is unclear if the observed statistical association can be interpreted as causal. (See Hainmueller and Hopkins (2014) on the recent research aimed to strengthen causal inference in studies of the attitudes towards immigrants). More recently, several studies looked at the macrolevel predictors of xenophobic views at a regional rather than national level. Hjerm (2009) studied attitudes towards immigrants at the municipal level in Sweden and concluded that the proportion of immigrants was not associated with the attitudes towards them. Evidence from the UK suggested that attitudes towards immigrants in London where many 
foreigners resided were better than in other parts of the country, even among white Britons (Blinder, 2011). Rustenbach (2010) used the ESS data and did not find an effect of the number of immigrants on attitudes either at the regional or national levels. Contrary to this, in the regionallevel analysis based on the ESS data Markaki and Longhi (2013) found a positive association between the proportion of immigrants born outside the EU and the anti-immigrant views.

The literature in this field has often treated immigrants as a homogeneous group. However, the countries of origin of immigrants are different from one European country to another and public attitudes are likely to vary depending on immigrants' ethnicity. Ford (2011) provided evidence that in Britain immigration from Australia and Western Europe faced weaker public opposition than immigration from Africa, South Asia and the Caribbean. In Switzerland immigrants from former Yugoslavia and Turkey were perceived more negatively than immigrants from northern and western European countries (Hainmueller and Hangartner, 2013). Bridges and Mateut (2014) showed that Europeans were more likely to oppose immigration of racially different groups. Incorporating ethnic heterogeneity of immigrant populations is important for a more nuanced understanding of public attitudes towards them.

Some ideas from social psychology may be helpful in this regard. Hagendoorn (1995) reviewed the studies of ethnic hierarchies based on various measures of social distance between ethnic groups (mostly survey questions about ethnic preferences in personal relationships). He identified three main components of ethnic hierarchies. First, almost 
all ethnic groups prefer social contacts within their own group (ingroup preference). Second, when it comes to contacts with members of other ethnic groups, there is a hierarchy of preferences that is shared within the same group (ingroup consensus). A number of studies in Europe, the USA and Canada demonstrated that people of Northern European origin were usually placed at the top of the hierarchy, followed by South and Eastern Europeans, while Asians and Africans were at the bottom of the hierarchy. Finally and perhaps most surprisingly, members of different ethnic groups, including those that are placed rather low in the ethnic hierarchy, seem to accept it (intergroup consensus).

Following this literature, this paper seeks to answer three research questions. First, does the labour market competition theory explain antiimmigrant attitudes in Russia? The paper tests this by looking at the association between personal socio-economic position and attitudes to-

wards immigrants. Second, is there a significant regional variation in views on immigrants and do regional level covariates such as the immigrant concentration and state of economy contribute to explaining it? This question seeks to test the group threat theory. Finally, is there any heterogeneity in attitudes to different immigrant ethnic groups? Do they form an ethnic hierarchy and if yes, is it shared across ethnic groups populating Russia?

\section{Immigration to Russia}

Russia is a country with one of the largest immigrant populations in the world. According to the OECD estimates (OECD, 2013), in 2010 there 
were 11.2 million foreign-born residents in Russia (7.9\% of its total population), second only to the USA with their foreign-born population of 40.4 million. This estimate is based on the 2010 Russian census and may be somewhat misleading, as ethnic Russians born outside Russia in the Soviet time (in Ukraine, Central Asia, etc.) were also counted as foreignborn. Another estimate comes from the Russian Federal Migration Office (FMO) that regularly publishes data on the number of foreign passport holders present in Russia. The data come from registering people entering and leaving Russia at border checkpoints. As of 14 December 2012, this number was 10.3 million (Bessudnov, 2012). Clearly, there is a difference between the FMO data counting foreign nationals and the census data on ethnicity and migration status. FMO data include temporary visitors, but not naturalised immigrants. On the other hand, census data are particularly unreliable when it comes to the number of immigrants as many of them were not surveyed.

History of immigration in post-Soviet Russia comprises of several waves. After the collapse of the USSR in 1991, ethnic Russians living in former Soviet republics (particularly Kazakhstan) started to return to Russia. At the same time, there was a significant migrant influx to Russia of ethnic Armenians, Azerbaijanis and Georgians who were trying to escape violent ethnic conflicts and severe economic problems in the Caucasus. According to the 2010 census, there were 1.2 million Armenians in Russia, which made them the seventh largest ethnic group in the country (after Russians, Tatars, Ukrainians, Bashkirs, Chuvashes and Chechens). Azerbaijanis numbered 0.6 million. 
Economic recovery that began in the 2000s brought in a new wave of immigrants, mostly attracted by new opportunities in the labour market. They mostly came from Ukraine, Moldova and Central Asian states, particularly Uzbekistan, Tajikistan, and Kyrgyzstan. Legal obstacles for mass immigration have been low since Russia has a visa free regime with most former Soviet republics except the Baltic states, Georgia and Turkmenistan. The FMO data showed that there were 2.3 million Uzbek nationals in Russia in December 2012 while the number of Uzbeks accounted for in the 2010 census was only 0.3 million. The number of Tajiks was 1.1 million in the FMO data and 0.2 million in the census. The FMO reported 1.4 million Ukrainian passport holders and Ukrainians numbered 1.9 million in the census. Many of them moved to Russia long ago and naturalised so these two groups are likely to only partially overlap. Among the other large groups reported in the FMO data there were nationals of Kazakhstan, Kyrgyzstan and Moldova, each of these countries having 0.5 million citizens in Russia. Many immigrants in this more recent wave were employed in low-skilled manual jobs in the service sector, construction, industry and agriculture (Lokshin and Chernina, 2013). ${ }^{1}$

As follows from these data, most immigrants came to Russia from the former Soviet states. Immigration from outside the former USSR was limited. The largest community was the Chinese whose number is

\footnotetext{
${ }^{1}$ The 2014-15 conflict in Eastern Ukraine brought in to Russia a large number of refugees and forced migrants and changed the relative proportions of immigrants from different countries. As of 2 July 2015, there were 2.6 million Ukrainian, 2.2 million Uzbek and 1 million Tajik nationals in the country. By comparing these figures to the 2012 data we can roughly estimate the number of Ukrainian citizens moving to Russia after the beginning of the military conflict at about one million.
} 
often exaggerated in the media. In reality, the 2010 census counted only 30,000 Chinese, and the FMO data had about 200,000 Chinese nationals.

Apart from immigration from outside of Russia, there were significant internal migration flows. Some of them consisted of ethnic Russians moving from one region to another whereas others included other ethnic groups. In particular, there was a significant out-migration from the North Caucasus, one of the poorest regions in the country with a high unemployment rate, populated by various Dagestani ethnic groups, Chechens, Ingushes, Ossetians, Kabardins, Karachays, and other ethnic groups. Members of these groups are mostly Russian citizens, but may speak Russian with an accent, are culturally different from ethnic Russians and are often perceived as strangers in ethnically Russian regions and metropolitan centres. On the other hand, Ukrainian and Belarusian migrants blend in much more easily, usually being indistinguishable from ethnic Russians in appearance and often speaking Russian as their mother tongue.

\section{Attitudes to immigrants in Russia}

Attitudes to immigrants in Russia are far from welcoming. The ESS in 2012 included a question on whether a country was made a better or worse place to live by people coming from other countries, measured on an 11-point scale where 0 was a "worse place to live" and 10 was a "better place to live". The average response for Russia was 3.3. This made Russia together with Cyprus two countries with the strongest anti-immigrant attitudes in the ESS sample of 29 European states. The Levada Centre, 
a Russian polling firm, regularly conducts a survey on the social and economic issues Russians are most concerned with. In 2013 27\% said that they were concerned with the inflow of immigrants (compared to $7 \%$ in 2005) making it the eighth most pressing issue out of 24 (far behind inflation and poverty that were the most popular responses) (LevadaCentre, 2013). According to a Public Opinion Foundation survey, in Moscow immigration was considered by respondents to be the second most pressing issue, after transportation problems and traffic jams (FOM, 2013).

As space is limited, we do not discuss here all of the existing literature on ethnic prejudice and immigration in Russia, but rather focus on the studies that assessed xenophobic attitudes quantitatively with survey data. Using data from a student survey conducted in 1991-92, Hraba et al. (1997) compared ethnic prejudice among Russians, Tatars and Ukrainians in several locations in the former USSR. The results showed that Russian students were more prejudiced when they had a majority rather than a minority status, but there was no difference across locations for Ukrainians and Tatars. With the data from the same survey, Hagendoorn et al. (1998) studied perceived ethnic hierarchies in the former USSR. In most ethnic groups and locations in-groups were placed on the top of the social distance hierarchy. Interestingly, the remaining part of the ethnic hierarchy was quite stable across groups and locations, with ethnically Slavic groups generally preferred to Asian groups, even by non-Slavic groups.

Alexseev (2010) analysed data from surveys of about 3,000 individuals conducted in 2005-07 by the Levada Centre across four regions in the 
Russian South, with a particular focus on mutual attitudes among Russia's ethnic groups. He found that ethnic Russians were generally more hostile towards immigrants than non-Russians and among native ethnic minorities groups who had titular status in their ethnic republics were more negative towards immigrants than non-titular groups. Gorodzeisky et al. (2014) looked at predictors of anti-immigrant attitudes in the Russian sample of the ESS 2006 (about 2,000 individuals). The theoretical ambition of the study was to test if the competition and cultural models applied to the study of anti-immigrant attitudes in Western Europe could be used in Russia. Their results showed that neither the socioeconomic position of individuals nor their level of political conservatism predicted anti-immigrant sentiment. Herrera and Kraus (2013a) put forward several theoretical hypotheses regarding the association between national identity and xenophobia and discussed the opportunities for regional analysis of xenophobic attitudes. In a separate paper Herrera and Kraus (2013b) tested whether stronger national identity was associated with increased xenophobia using data from a survey conducted in 200304 by Gerber and Mendelson (11,000 individuals, 43 regions).Different types of national identity had different effects on xenophobia, and the intensity of anti-minority views depended on the minority in question (Roma and Chechens being the least acceptable while Azerbaijanis and Muslims somewhat more acceptable). The analysis was conducted at the individual level, without testing the effects of macro-level regional predictors. 


\section{Data and modelling strategy}

The data for this study come from a survey conducted by the Public Opinion Foundation (FOM) in 2011. FOM is a Russian polling firm that was founded in 1992 and has an extensive experience of conducting nationally representative surveys. The sample consists of 24,500 individuals surveyed in 49 Russian regions (out of 83). Missing regions include ethnic republics in the North Caucasus and Siberia and some regions in central Russia and the Russian North (see the map in Figure 1). Although, strictly speaking, the sample was not designed to be representative at the national level and the selection of regions was largely dictated by convenience and was not random, the regions in the sample represent about $77 \%$ of Russia's population.

Multistage stratified sampling was used to sample 500 individuals aged over 17 in each region so that the design of the survey is suitable for cross-regional comparisons. To get descriptive statistics at the national level (or rather at the level representing $77 \%$ of Russia's population) we apply weight coefficients inversely proportional to the regional population size. All the interviews were conducted using the face-to-face method at the respondents' homes. Table A1 in the Appendix presents descriptive

statistics (both unweighted and weighted) for the variables used in the analysis and compares them with the data from the 2010 census.

The survey questionnaire was designed specifically to address the problem of immigration. To operationalize attitudes towards immigrants we used the questions about how a respondent would feel if an ordinary immigrant family had settled near their place. Six separate ques- 
tions were asked about immigrants from Ukraine, Moldova, the Caucasus (Azerbaijanis, Armenians, Georgians), the North Caucasus (Dagestanis, Chechens, Cherkessians, etc.), Central Asia (Kyrgyz, Uzbeks, Tajiks) and South-East Asia (Chinese, Vietnamese, Koreans). The ethnic groups in the parentheses above are the ones that were specified in the survey questionnaire. The answers were recorded on a scale from one (very positive) to five (very negative). Note that immigrants from the North Caucasus who are Russian nationals were listed along with immigrants from outside of Russia. The survey question about attitudes to potential neighbours is standard in social distance research and in our case it allows us to study attitudes to different immigrant ethnic groups separately.

There were 3,110 people (13\% of the sample) who did not answer the question about at least one of the six ethnic groups. This response was least popular in case of immigrants from Ukraine (3\%) and most popular for immigrants from South-East Asia (6\%) with whom people in many Russian regions have little or no contact. To avoid dropping these cases we fill in missing values applying multiple imputation (as implemented in the Amelia package in R (Honaker et al., 2011)). The results reported below are based on the analysis of imputed datasets.

The variables measuring attitudes towards different groups of immigrants correlate well and produce an index with Cronbach's alpha 0.89. For ethnically non-Russian respondents we exclude the items measuring attitudes to their own or close ethnic groups (for example, for Chechens attitudes to immigrants from the North Caucasus, etc.). The final index was calculated as an average response to the items measuring attitudes 
to the ethnic groups different from the respondent's ethnic group. The index ranges from one (least xenophobic) to five (most xenophobic).

The statistical analysis presented below is based on the following logic. Since the data have a two-level structure (individuals in regions) we employ linear mixed effects (multilevel) modelling. First, we estimate a model with individual-level predictors only. Some of the predictors (such as employment status) aim to test the labour market competition theory. Others are included to investigate the association between other socio-demographic characteristics and attitudes towards immigrants and compare the results with the findings from previous studies conducted mostly in Western Europe. Individual level predictors include sex, age, education, individual monthly income, employment status and occupation, ethnicity, type of residence, religious denomination, personal experience of immigration and experience of hiring an immigrant.

Next, we add to the model regional level predictors. We use two independent measures of immigrant population density: the regional proportion of legally employed immigrants and the number of international money transfers in the region. These variables test the group threat theory. According to the official data, in 20111.76 million foreign nationals had either a work permit or a patent that allowed them to be legally employed. It is more difficult to estimate the number of those employed illegally, but it was likely to be at least just as many. Work permit and patent quotas were assigned at the regional level, and we use the number of legally employed foreign nationals in the region (divided by the size of the regional population aged over 16) as a proxy for immigrant 
concentration.

To check robustness of our findings, we employ another measure of immigrant concentration. The Bank of Russia keeps statistics on the number of international money transfers made by individuals without opening a bank account. While these data include all the payments made by Russian citizens and immigrants, in practice this type of payment is typical for the money transfer systems that immigrants often use for sending remittances. We only use the data for the payments made to individuals (not organisations) outside of Russia. The earliest year for which these data are available is 2013. As we are mostly interested in the regional differences, we assume that the geographical distribution of immigrants did not change significantly in 2013 compared to 2011. For the analysis we use the data on the number of money transfers divided by the size of the regional population aged over 16 .

To test a hypothesis that regional economic conditions may be associated with attitudes to immigrants we employ two measures: the regional unemployment rate and monthly income-to-subsistence ratio (to account for regional differences in the consumer price index) in 2011. The data for both variables come from the official surveys conducted by the Russian Statistical Office. We hypothesize that education may have a liberalizing effect on attitudes towards immigrants not only at the individual, but also at the group level and to test this we introduce a variable measuring the proportion of people with a higher education in the regions. Finally, ethnic composition of the region may have an effect on attitudes towards immigrants even after controlling for ethnicity of individual respondents. 
More specifically, more ethnically diverse regions may be less xenophobic. To test this, we use the proportion of ethnic Russians in the regions as a measure of ethnic diversity. The data for the proportion of people with a higher education and proportion of ethnic Russians come from the 2010 census.

Finally, to explore the ethnic hierarchy in attitudes to immigrants we conduct an analysis of mean attitudes towards different immigrant ethnic groups by ethnicity.

\section{$5 \quad$ Results}

Russians are sceptical about immigration and immigrants. $53 \%$ of the respondents said that they would support banning permanent immigration from outside of Russia. Answering the question about their attitudes towards potential immigrant neighbours, only $15 \%$ of the respondents said they would be 'rather' or 'completely negative' about Ukrainians (the survey was conducted three years before the Russian-Ukrainian conflict in 2014-15). For immigrants from Moldova this figure goes up to 25\% while for the Caucasus it was 53\%, for South-East Asia 54\%, for Central Asia 56\%, and for the North Caucasus 61\%. A clear ethnic hierarchy emerges from these numbers as Russians seem to be more welcoming to Ukrainians and Moldovans and more hostile towards the other four groups. Note that, despite the North Caucasus being part of Russia the attitudes towards people from this region are most negative.

The first step in the analysis is to look at the individual level correlates of anti-immigrant attitudes, with a particular focus on the socio-economic 
characteristics of individuals. Table 1 presents a random-intercept model with all the individual predictors of xenophobic attitudes. The bivariate associations are similar in direction and size so the coefficients from the model with multiple predictors may be given a straightforward descriptive interpretation.

(Table 1 about here)

Men and women are not significantly different on their attitudes to immigrants. Older people are slightly less xenophobic than younger, but the effect size is very small. People with a higher education are less hostile to immigrants than people with a secondary and vocational education, but the difference is not large. Controlling for other factors, the difference between people with higher and secondary education is 0.12 , or about $13 \%$ of the standard deviation of the dependent variable.

Importantly for our research question, the effects of employment status and occupation are also small and often not statistically significant. Non-manual employees are somewhat less xenophobic than manual workers, but the difference between them is just 0.08 . There is no statistically significant difference between blue collar workers and the unemployed, and between the unemployed and those not in the labour force. Income differences do not contribute to explaining the outcome variance either.

Interestingly, people living in the countryside are least xenophobic while the population of big cities is most xenophobic. This effect is opposite to what was previously found in Europe. The experience of immigration has an expected effect: those who have immigrated themselves, especially recently, are on average more tolerant. People who have 
had an experience of hiring immigrants to conduct some work for them are somewhat less negative towards newcomers. Two interpretations are possible: contact with the immigrants in a work context could improve attitudes, or less xenophobic people are more likely to hire foreigners in the first place.

Religion is not very important as there is no significant difference in the attitudes of Orthodox Christians and atheists. Smaller groups of Buddhists, religious Jews and non-Orthodox Christians exhibit less negative attitudes. There is not much difference between the attitudes of Orthodox Christians and Muslims, although in this case the effect is hard to separate from ethnicity. The effects of ethnicity are explored in more detail below.

The predictive power of the model with all the individual level covariates is very low. All individual level predictors jointly account for only $3 \%$ of the outcome variance $\left(R^{2}\right.$ was calculated with a method suggested by Snijders and Bosker (2012, ch.7)). Decomposition of $R^{2}$ using hierarchical partitioning (Grömping, 2006) suggests that ethnicity is by far the most important predictor, followed by immigration experience, location, religion and education (in this order).

(Table 2 about here)

Next, we consider regional variation in anti-immigrant attitudes and the effects of contextual regional level covariates. Figure 1 presents a map that plots regional mean values of the index of anti-immigrant attitudes. The darker colours show more xenophobic regions (Moscow, Leningrad region, Nizhny Novgorod and Kaluga regions) and the lighter 
colours mark the less xenophobic regions (Krasnodar kray, Omsk and Khabarovsk regions, Tatarstan). The general pattern is that regions in Central Russia are somewhat more xenophobic than in the South, the Urals, Siberia and the Far East.

(Figure 1 about here)

Regional contribution to explaining the total outcome variance is small. The intraclass correlation in an empty random-intercept model is 0.02 that suggests that only $2 \%$ of the total outcome variance can be accounted for by regional differences. However, the likelihood ratio test comparing the linear model with all the individual level predictors and the model with a regional random intercept added shows that incorporating the regional level of analysis improved the model fit $\left(L^{2}=377\right.$, $d f=1, p<0.01)$.

Figure 1: Regional means of the index of anti-immigrant attitudes

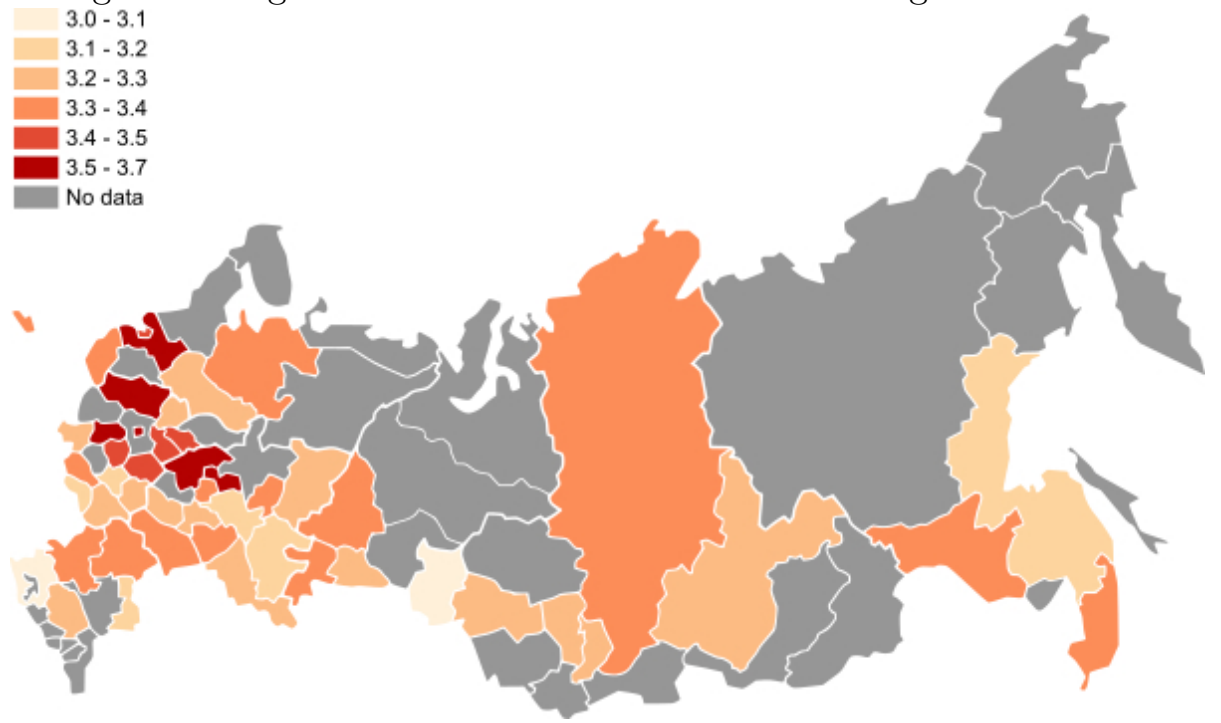


Figure 2 presents the scatter plots of regional intercepts predicted from the model in Table 1 (i.e., after accounting for all the individual level differences between the regions ${ }^{2}$ ) and six regional level covariates: income, unemployment, education, the proportion of ethnic Russians and immigrant concentration measured in two alternative ways as described above. Solid lines show linear regression estimates while dashed lines represent regression with a possible outlier, Moscow, excluded from the analysis.

\section{(Figure 2 about here)}

The association between regional unemployment and anti-immigrant attitudes is negative (when unemployment is high ethnic prejudice is weaker), although it is not statistically significant at the $95 \%$ level. There is virtually no association between regional income and ethnic prejudice. However, once Moscow (an outlier) is taken out from the analysis, a negative association appears: poorer regions are more xenophobic. Both measures of immigrant concentration (correlated with $r=0.52$ ) show a significant positive association with anti-immigrant attitudes. The proportion of people with a higher education is not statistically significantly associated with ethnic prejudice; the association disappears completely is Moscow is taken out from the analysis. Finally, in more ethnically Russian regions the attitudes to immigrants are somewhat more negative.

(Table 3 about here)

\footnotetext{
${ }^{2}$ After adding the individual level predictors to the empty model with regional intercepts the regional level outcome variance diminishes by $5 \%$. This suggests that only about $5 \%$ of the regional outcome variance can be explained by the differences in the socio-demographic composition of the population across the regions.
} 
Figure 2: Regional level predictors of anti-immigrant attitudes
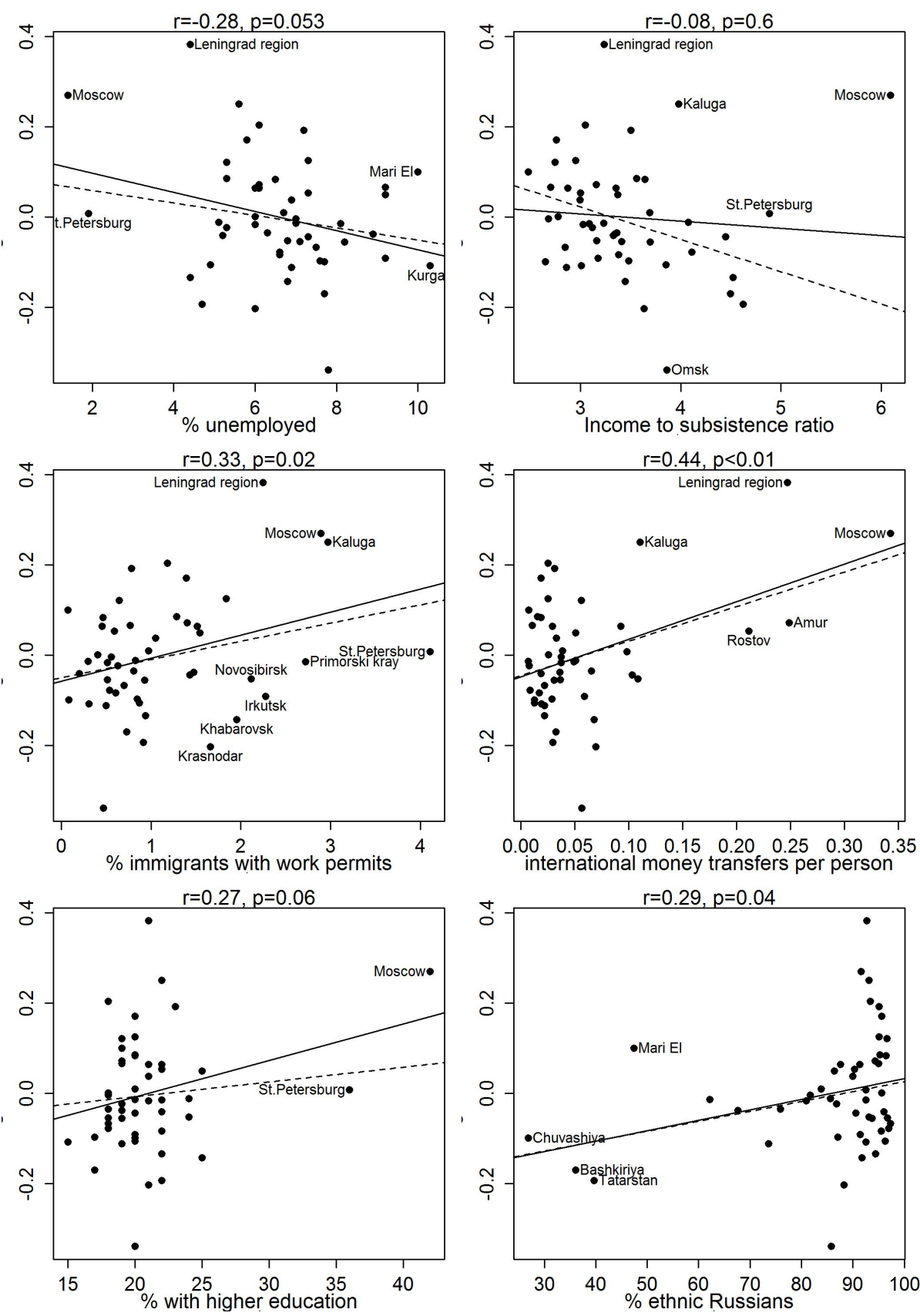
At the next stage we build a model with several regional level predictors. Variables that were not statistically significant in the bivariate analysis (education and unemployment) were excluded from the model. We start with a model with immigrant concentration using the percentage of immigrants with work permits as its measure (model 1 in table 3 ). At the next stage, we add a variable for income and also a dummy variable for Moscow to account for Moscow being an outlier (model 2). Both income and immigrant concentration are statistically significant predictors of anti-immigrant attitudes once they are included in the model together. Finally, once controlled for these two variables, adding the percent of ethnic Russians does not improve the model (model 3).

(Table 4 about here)

We estimate separate models for the attitudes towards immigrants from different regions (see table 4). Immigrant concentration is only associated with attitudes towards immigrants from the Caucasus and Central and South-East Asia, but not Ukraine or Moldova. The effect of income is also weaker in case of immigrants from Ukraine and Moldova, and for the former it does not reach the conventional level of statistical significance.

As a robustness check, we re-estimate all the models with an alternative measure of immigrant concentration (the number of international money transfers). The results are very similar (see tables A3 and A4 in the appendix). The only noteworthy difference is that the alternative measure of immigrant concentration is statistically significantly associated with the attitudes towards immigrants from Moldova (but not from 
Ukraine).

The next analytic step is to consider ethnic heterogeneity in the attitudes towards immigrants from different regions. Table 2 presents mean attitudes of different ethnic groups towards immigrants from six different regions. To simplify the presentation we do not report confidence intervals, but only include the ethnic groups with more than 30 respondents in the sample. ${ }^{3}$ The most interesting finding from this analysis is that the preference order across all ethnic groups is quite similar. It is not surprising that Russians prefer more culturally similar Ukrainians to immigrants from the Caucasus and Central Asia. However, Ukrainians are the most preferred immigrant group across all the ethnic groups, including respondents from Central Asia and the Caucasus. The preferences of Tatars and Bashkirs are ordered in almost exactly the same way as the preferences of Russians and Ukrainians. Azerbaijanis, Armenians and Tajiks are more positive about Ukrainians and Moldovans than about immigrants from Central Asia and the North Caucasus.

There is not much difference in the effects of other individual level predictors on xenophobic attitudes towards immigrants from different regions. The results from six separate models testing this are available in table A2 in the appendix.

\footnotetext{
${ }^{3}$ We include ethnic groups from former Soviet republics (Ukrainians, Belarussians, etc.) as in our survey most of them are either second (or more) generation immigrants or arrived to Russia more than 10 years before the survey.
} 


\section{Discussion}

Are determinants of anti-immigrant attitudes in Russia different from Western Europe? The individual level analysis shows that some predictors have similar patterns of association with anti-immigrant prejudice as reported in the analyses with European data (Ceobanu and Escandell, 2010). People with higher education are more tolerant to immigrants while gender, age and income appear to be less important. An important difference between Russia and Western Europe is the effect of location. While in Europe people living in cities are more cosmopolitan and tolerant than those who populate the countryside, in Russia the effect is the opposite. London, New York and Moscow all attract a significant number of immigrants, but while the former two generally welcome diversity Moscow remains one of the most xenophobic places in Russia.

The results presented above show that in Russia individual economic circumstances are only weakly associated with anti-immigrant sentiments. The unemployed and manual workers hold only marginally more negative views on immigrants than non-manual employees. Personal income is not associated with ethnic prejudice. Thus, answering the first research question, we may conclude that the theory that explains negative attitudes towards immigrants by the natives' fear of economic competition does not find much support in our data. It is hard to make definite conclusions with cross-sectional data though, and longitudinal data would be better suited to explore whether personal economic trajectories have any effect on ethnic prejudice.

The group threat theory seems to be more relevant to explaining anti- 
immigrant prejudice in Russia. If the theory is correct, a higher concentration of immigrants should lead to more negative attitudes toward them (although in many cases natives overestimate the size of immigrant populations and this can still trigger the group threat mechanism). We do indeed observe a positive correlation between immigrant concentration at the regional level (measured in two alternative ways) and anti-immigrant attitudes. As usual in cross-sectional analysis, causality is hard to prove here. We can exclude reverse causation as it is unlikely that immigrants are attracted to the regions where locals are particularly negative about them. It is possible, of course, that the regions with a high immigrant concentration may have other characteristics that affect anti-immigrant attitudes. However, in our data immigrant concentration is associated with the attitudes towards immigrants from the Caucasus and Central Asia, but not Ukrainians who are generally not seen as a threat by the native population. The effect of the immigrant groups size seems to be stronger for the groups that are placed lower in the ethnic hierarchy. This strengthens the claim that the association between immigrant concentration and the views of natives is causal. Let us assume that there are exogenous confounders at the regional level that explain the association between immigrant concentration and attitudes to immigrants. It is hard to see then why this association exists for the attitudes to immigrants from the Caucasus and Central Asia, but not from Ukraine.

While individual income is not a significant predictor of anti-immigrant views we do find some effect of income at the regional level (controlling for immigrant concentration and after excluding Moscow as an outlier). 
Poorer regions are more xenophobic, although the effect size is quite small. Perhaps people in these regions are more worried about the effect of immigration on the state of economy. This is what Hainmueller and Hopkins (2014) called "sociotropic" economic concerns that should not be confused with the effect of personal economic circumstances. Interestingly, these results (both for the relative size of the immigrant population and the contextual level economic conditions) are consistent with what was previously reported for European countries in the analysis at the national (Quillian, 1995) and regional (Markaki and Longhi, 2013) levels.

In respect to our third research question, we find that attitudes towards immigrants depend on their country of origin. Not all immigrants are equally unwelcome. Most Russians have little aversive prejudice towards Ukrainians and, to a lesser extent, Moldovans, while immigrants from the Caucasus and Central Asia face a much stronger opposition. Respondents' ethnicity also affects their views. Ethnic Russians are not very different in their anti-immigrant views from Turkic and Finno-Ugric ethnic groups from the Urals and Volga region. However, respondents from former Soviet republics, especially in the Caucasus and Central Asia, many of them first- or second generation immigrants themselves, are more tolerant to newcomers.

Perhaps the most surprising finding in this study is a high degree of inter-group consensus on the ethnic hierarchy of immigrant groups. The preferences of all the ethnic groups in the sample are remarkably similar when it comes to ethnicity of their potential neighbours. It may be tempting to think that ethnic Russians generally accept Ukrainian 
immigrants because of the cultural and linguistic proximity between these two ethnic groups. However, Tatars, Azerbaijanis or Kazakhs also prefer Ukrainian and Moldovan neighbours to immigrants from Central Asia and the Caucasus who may be closer to them culturally and religiously.

The phenomenon of inter-group consensus on ethnic hierarchy is well known in social psychology and was reported previously for Russia by Hagendoorn et al. (1998). Hagendoorn et al. noted that it was also found in other countries and that "a common element in these hierarchies is that North Europeans are placed at the top, in the middle are Southern and Eastern Europeans, while Asians and Africans generally occupy positions at the lower end of the scale". The survey instrument in our study does not include questions about attitudes to North and Western Europeans, but the relative positions of other groups confirm Hagendoorn et al.'s conclusions. Hagendoorn (1995) explains this consensus by status considerations: ethnic groups that are perceived as having lower status do not want to further endanger it by association with other groups with lower status.

A more fundamental difference between Russia and Western Europe is that in Russia statistical models explain only a tiny part of the total variance of attitudes. While the direction of some effects is the same as in Western Europe, their size and predictive power are considerably smaller. After incorporating all the individual level predictors and accounting for regional heterogeneity our models leave about $95 \%$ of the outcome variance unexplained. This is consistent with the results reported previously by Gorodzeisky et al. (2014) who noticed a much weaker predictive 
power of the models explaining attitudes towards immigrants in Russia compared to other European countries. Individual socio-economic characteristics that are standard in sociological research fail to structure the attitudes of Russians, and knowing a person's sex, age, level of education, occupation, ethnicity and location provides us with very little information about their views on immigration. Other, unobserved factors seem to be more important. These can be the effects of exposure to the media, personal psychological characteristics (such as social dominance orientation) or more idiosyncratic personal trajectories and attitudes. We leave the exploration of these factors for future research. 


\section{References}

Alexseev, M.A. 2010. "Majority and minority xenophobia in Russia: The importance of being titulars." Post-Soviet Affairs 26:89-120.

Bessudnov, A. 2012. "Skolko gastarbaiterov v Rossii? [How many guest workers are there in Russia?]." Slon.ru, http://slon.ru/russia/ skolko_gastarbayterov_v_rossii-870263.xhtml. Accessed on 30 July 2015.

Blinder, S. 2011. "UK public opinion toward immigration: Determinants of attitudes." The Migration Observatory Briefing, University of Oxford.

Bridges, S. and S. Mateut. 2014. "Should they stay or should they go? Attitudes towards immigration in Europe." Scottish Journal of Political Economy 61:397-429.

Ceobanu, A.M. and X. Escandell. 2010. "Comparative analyses of public attitudes toward immigrants and immigration using multinational survey data: A review of theories and research." Annual Review of Sociology 36:309-328.

Dustmann, C. and I.P. Preston. 2007. "Racial and economic factors in attitudes to immigration." The B.E. Journal of Economic Analysis $\mathscr{E}$ Policy 7:Article 62.

FOM. 2013. "A survey of Muscovites. City's problems: successes and failures. [Opros moskvichey. Gorodskie problemy: uspehi i neudachi]." http://fom.ru/Nastroeniya/10817. Accessed on 4 September 2014. 
Ford, R. 2011. "Acceptable and unacceptable immigrants: the ethnic hierarchy in British immigration preferences." Journal of Ethnic and Migration Studies 37:1017-1037.

Gorodzeisky, A., A. Glikman, and D. Maskileyson. 2014. "The nature of anti-immigrant sentiment in post-socialist Russia." Post-Soviet Affairs $31: 115-135$.

Grömping, U. 2006. "Relative importance for linear regression in R: The package relaimpo." Journal of Statistical Software 17:1-27.

Hagendoorn, L. 1995. "Intergroup biases in multiple group systems: The perception of ethnic hierarchies." European Review of Social Psychology 6:199-228.

Hagendoorn, L., R. Drogendijk, S. Tumanov, and J. Hraba. 1998. "Interethnic preferences and ethnic hierarchies in the former Soviet Union." International Journal of Intercultural Relations 22:483-503.

Hainmueller, J. and D. Hangartner. 2013. "Who gets a Swiss passport? A natural experiment in immigrant discrimination." American Political Science Review 107:159-187.

Hainmueller, J. and M.J. Hiscox. 2007. "Educated preferences: Explaining attitudes toward immigration in Europe." International Organization 61:399-442.

Hainmueller, J. and D.J. Hopkins. 2014. "Public attitudes toward immigration." Annual Review of Political Science 17:225-249. 
Herrera, Y.M. and N.B. Kraus. 2013a. "National identity and xenophobia in Russia: Opportunities for regional analysis." In Russia's Regions and Comparative Subnational Politics, edited by W.M. Reisinger, pp. 102-119. Routledge.

Herrera, Y.M. and N.B. Kraus. 2013b. "Pride vs. prejudice: Xenophobia and national identity in Russia." Unpublished paper.

Hjerm, M. 2009. "Anti-immigrant attitudes and cross-municipal variation in the proportion of immigrants." Acta Sociologica 52:47-62.

Honaker, J., G. King, and M. Blackwell. 2011. "Amelia II: A Program for Missing Data." Journal of Statistical Software 45:1-47.

Hraba, J., C.S. Dunham, S. Tumanov, and L. Hagendoorn. 1997. "Prejudice in the former Soviet Union." Ethnic and Racial Studies 20:613627.

LevadaCentre. 2013. "Problems and concern of Russians. [Problemy i trevogi rossiyan]." http://www.levada.ru/03-09-2013/ problemy-i-trevogi-rossiyan. Accessed on 4 September 2014.

Lokshin, M. and E. Chernina. 2013. "Migranty na rossiyskom rynke truda: Portret i zarabotnaya plata. [Migrants in the Russian labor market: Profile and earnings]." HSE Economic Journal 1:44-80.

Markaki, Y. and S. Longhi. 2013. "What determines attitudes to immigration in European countries? An analysis at the regional level." Migration Studies 1:311-337. 
Mayda, A.M. 2006. "Who is against immigration? A cross-country investigation of individual attitudes toward immigrants." The Review of Economics and Statistics 88:510-530.

Meuleman, B., E. Davidov, and J. Billiet. 2009. "Changing attitudes toward immigration in Europe, 2002-2007: A dynamic group conflict theory approach." Social Science Research 38:352-365.

OECD. 2013. International Migration Outlook 2013. OECD Publishing.

Quillian, L. 1995. "Prejudice as a response to perceived group threat: Population composition and anti-immigrant and racial prejudice in Europe." American Sociological Review 60:586-611.

Rustenbach, E. 2010. "Sources of negative attitudes toward immigrants in Europe: A multi-level analysis." International Migration Review $44: 53-77$.

Scheepers, P., M. Gijsberts, and M. Coenders. 2002. "Ethnic exclusionism in European countries. Public opposition to civil rights for legal migrants as a response to perceived ethnic threat." European Sociological Review 18:17-34.

Schneider, S.L. 2008. "Anti-immigrant attitudes in Europe: Outgroup size and perceived ethnic threat." European Sociological Review 24:5367.

Semyonov, M., R. Raijman, and A. Gorodzeisky. 2006. "The rise of anti-foreigner sentiment in European societies, 1988-2000." American Sociological Review 71:426-449. 
Semyonov, M., R. Raijman, and A. Gorodzeisky. 2008. "Foreigners' impact on European societies. Public views and perceptions in a crossnational comparative perspective." International Journal of Comparative Sociology 49:5-29.

Snijders, T.A.B. and R.J. Bosker. 2012. Multilevel Analysis. An Introduction to Basic and Advanced Multilevel Modeling. Sage. 
Table 1: Individual-level predictors of xenophobic attitudes

\begin{tabular}{|c|c|c|}
\hline & coef. & s.e. \\
\hline Intercept & $3.60^{* * *}$ & $(0.04)$ \\
\hline Male & 0.004 & $(0.01)$ \\
\hline Age (centred around the mean) & $-0.002^{* * *}$ & $(0.0005)$ \\
\hline \multicolumn{3}{|l|}{ Education (ref. Secondary or less) } \\
\hline Lower vocational & $0.06^{* *}$ & $(0.02)$ \\
\hline Secondary specialized & $-0.04^{* *}$ & $(0.01)$ \\
\hline Higher incomplete & $-0.08^{* *}$ & $(0.04)$ \\
\hline Higher or $\mathrm{PhD}$ & $-0.12^{* * *}$ & $(0.02)$ \\
\hline \multicolumn{3}{|l|}{ Ethnicity (ref. Russian) } \\
\hline Bashkir/Chuvash & $0.16^{* * *}$ & $(0.05)$ \\
\hline Belorussian & $-0.23^{* * *}$ & $(0.09)$ \\
\hline Georgian/Armenian/Azerbaijani & $-0.83^{* * *}$ & $(0.07)$ \\
\hline Kazakh & $-0.19^{* *}$ & $(0.09)$ \\
\hline Kyrgyz/Tajik/Uzbek & $-0.90^{* * *}$ & $(0.12)$ \\
\hline Mari/Mordva/Udmurt & $0.15^{* * *}$ & $(0.05)$ \\
\hline from the North Caucasus & $-0.41^{* * *}$ & $(0.11)$ \\
\hline Tatar & -0.06 & $(0.05)$ \\
\hline Ukrainian & -0.02 & $(0.05)$ \\
\hline Other & $-0.21^{* * *}$ & $(0.05)$ \\
\hline No data & -0.11 & $(0.12)$ \\
\hline \multicolumn{3}{|c|}{ Employment status / occupation (ref. Manual) } \\
\hline Non-manual & $-0.08^{* * *}$ & $(0.02)$ \\
\hline Unemployed & 0.02 & $(0.03)$ \\
\hline Not working and not looking for a job & -0.02 & $(0.04)$ \\
\hline Retired & -0.02 & $(0.02)$ \\
\hline Student & $-0.11^{* * *}$ & $(0.04)$ \\
\hline Other or NA & $-0.07^{*}$ & $(0.04)$ \\
\hline \multicolumn{3}{|l|}{ Income (ref. $<8,000$ rub.) } \\
\hline 8,000 to 15,000 rub. & -0.01 & $(0.02)$ \\
\hline 15,000 to 30,000 rub. & 0.02 & $(0.02)$ \\
\hline$>30,000$ rub. & -0.05 & $(0.04)$ \\
\hline No income & $0.05^{* *}$ & $(0.03)$ \\
\hline No answer & $0.07^{* * *}$ & $(0.02)$ \\
\hline \multicolumn{3}{|l|}{ Religion (ref. Orthodox Christian) } \\
\hline Buddhist & $-0.53^{* * *}$ & $(0.19)$ \\
\hline Judaist & $-0.66^{* * *}$ & $(0.26)$ \\
\hline Muslim & -0.06 & $(0.05)$ \\
\hline Not religious & -0.01 & $(0.02)$ \\
\hline Other Christian & $-0.27^{* * *}$ & $(0.06)$ \\
\hline No answer & -0.05 & $(0.04)$ \\
\hline \multicolumn{3}{|l|}{ Location (ref. City > 1 million) } \\
\hline Small city (100,000 to 1 million) & $-0.15^{* * *}$ & $(0.03)$ \\
\hline Town $(<100,000)$ & $-0.19^{* * *}$ & $(0.03)$ \\
\hline Countryside & $-0.23^{* * *}$ & $(0.03)$ \\
\hline
\end{tabular}


Table 1 - continued from previous page

\begin{tabular}{lcc}
\hline & coef. & s.e. \\
\hline Migration status (ref.: Always lived there) & & \\
Moved more than 10 years ago & $-0.08^{* * *}$ & $(0.01)$ \\
Moved less than 10 years ago & $-0.14^{* * *}$ & $(0.02)$ \\
No answer & 0.06 & $(0.1)$ \\
Hired an immigrant (ref.: Did not hire) & $-0.15^{* * *}$ & $(0.02)$ \\
\hline No obs. & 24500 & \\
No regions & 49 & 0.02 \\
Variance: intercept & 0.84 \\
Variance: residual & 0.03 \\
$R^{2}$ & 65364 \\
$L^{2}$ & 44 & \\
df & \\
\hline$* * * p<0.01, * * p<0.05,{ }^{*} p<0.1$ & \\
The random intercept model. The dependent variable varies from one \\
(least xenophobic) to five (most xenophobic). \\
The model was fitted using residual maximum likelihood (REML). \\
However, the deviance reported is from the model fitted with maximum \\
likelihood (ML), so that it can be used to construct likelihood ratio tests. \\
$R^{2}$ calculated according to the method in Snijders and Bosker (2012, ch.7). \\
\hline \hline
\end{tabular}


Table 2: Mean attitudes to immigrants from different regions by ethnic group

\begin{tabular}{lccccccc}
\hline ethnicity (n) & Ukraine & Moldova & Caucasus & Central Asia & South-East Asia & North Caucasus & mean \\
\hline Mordvin (87) & 2.9 & 3.1 & 3.9 & 3.8 & 4.0 & 3.9 & 3.6 \\
Mari (234) & 2.8 & 3.0 & 3.7 & 3.8 & 4.0 & 3.9 & 3.5 \\
Chuvash (455) & 2.7 & 2.9 & 3.7 & 3.6 & 3.8 & 3.8 & 3.4 \\
Russian (21211) & 2.6 & 2.9 & 3.6 & 3.7 & 3.8 & 3.8 & 3.4 \\
Bashkir (126) & 2.8 & 2.9 & 3.6 & 3.6 & 3.8 & 3.7 & 3.4 \\
Udmurt (147) & 2.8 & 3.0 & 3.5 & 3.6 & 3.7 & 3.7 & 3.4 \\
Khakas (77) & 2.7 & 2.9 & 3.5 & 3.4 & 3.6 & 3.7 & 3.3 \\
Tatar (765) & 2.6 & 2.8 & 3.3 & 3.3 & 3.5 & 3.5 & 3.2 \\
Ukrainian (375) & 1.9 & 2.5 & 3.5 & 3.5 & 3.7 & 3.7 & 3.1 \\
Belorussian (113) & 2.2 & 2.5 & 3.4 & 3.5 & 3.5 & 3.6 & 3.1 \\
German (67) & 2.3 & 2.6 & 3.2 & 3.2 & 3.5 & 3.5 & 3.0 \\
Kazakh (166) & 2.4 & 2.4 & 3.2 & 3.1 & 3.5 & 3.4 & 3.0 \\
Azerbaijani (58) & 2.1 & 2.2 & 2.5 & 2.9 & 2.8 & 2.7 & 2.6 \\
Armenian (136) & 2.0 & 2.1 & 2.1 & 2.7 & 2.5 & 2.5 & 2.4 \\
Tajik (32) & 1.9 & 2.2 & 2.4 & 2.3 & 3.5 & 3.8 & \\
\hline All (24500) & 2.5 & 2.8 & 3.6 & 3.7 & 3.8 & &
\end{tabular}

Only ethnic groups with $n>30$ included. The scale ranges from 1 to 5 where 1 is the most positive and 5 is the most negative attitude. Ethnic groups in rows and regions of origin in columns ordered according to the mean attitude. All the values were averaged across five imputed data sets. Weight coefficients applied. 
Table 3: Models with regional-level predictors Model 1 Model 2

Model 3

\begin{tabular}{lcccccc} 
& coef. & s.e. & coef. & s.e. & coef. & s.e. \\
\hline Constant & $3.6^{* * *}$ & $(0.05)$ & $3.9^{* * *}$ & $(0.12)$ & $3.8^{* * *}$ & $(0.16)$ \\
\% immigrants & $0.06^{* *}$ & $(0.02)$ & $0.07^{* * *}$ & $(0.02)$ & $0.06^{* *}$ & $(0.02)$ \\
income-to-subsistence ratio & & & $-0.11^{* * *}$ & $(0.03)$ & $-0.10^{* * *}$ & $(0.03)$ \\
Moscow & & & $0.48^{* * *}$ & $(0.15)$ & $0.47^{* * *}$ & $(0.15)$ \\
\% ethnically Russian & & & & & $\approx 0.01$ & $(\approx 0.01)$ \\
\hline n obs. & 24500 & 24500 & & 24500 & \\
n regions & 49 & 49 & & 49 & \\
$R^{2}$ & 0.03 & 0.04 & & 0.04 & \\
$L^{2}$ & 65358 & 65344 & & 65342 & \\
df & 45 & 47 & & 48 & \\
\hline
\end{tabular}

${ }^{* * *} p<0.01,{ }^{* *} p<0.05,{ }^{*} p<0.1$

The random-intercept models account for all individual-level predictors from Table 1, but the coefficients are not shown. Standard errors in the parentheses.

The dependent variable varies from one (least xenophobic) to five (most xenophobic).

The models were fitted using residual maximum likelihood (REML). However, the deviance reported is from the model fitted with maximum likelihood (ML), so that it can be used to construct likelihood ratio tests. First imputation was used to report $L^{2}$. 
Table 4: Models with regional-level predictors by region of immigration

\begin{tabular}{lcccccc} 
& Ukraine & Moldova & Caucasus & Central Asia & South-East Asia & North Caucasus \\
\hline Constant & $3.0^{* * *}$ & $3.4^{* * *}$ & $4.2^{* * *}$ & $4.3^{* * *}$ & $4.3^{* * *}$ & $4.4^{* * *}$ \\
\multirow{2}{*}{ \% immigrants } & $\approx 0.17)$ & $(0.14)$ & $(0.16)$ & $(0.16)$ & $(0.16)$ & $(0.16)$ \\
& $(0.03)$ & $(0.03)$ & $0.08^{* * *}$ & $0.11^{* * *}$ & $0.11^{* * *}$ & $0.09^{* * *}$ \\
income ratio & -0.07 & $-0.09^{* *}$ & $-0.11^{* *}$ & $-0.13^{* * *}$ & $-0.03)$ & $(0.03)$ \\
& $(0.05)$ & $(0.04)$ & $(0.04)$ & $(0.05)$ & $(0.05)$ & $-0.13^{* * *}$ \\
Moscow & $0.44^{* *}$ & $0.39^{* *}$ & $0.44^{* *}$ & $0.51^{* *}$ & $0.55^{* * *}$ & $(0.05)$ \\
& $(0.22)$ & $(0.18)$ & $(0.20)$ & $(0.20)$ & $(0.20)$ & $0.53^{* *}$ \\
\hline n obs. & 24500 & 24500 & 24500 & 24500 & 24500 & $240.21)$ \\
n regions & 49 & 49 & 49 & 49 & 49 & 49 \\
$R^{2}$ & 0.02 & 0.02 & 0.03 & 0.03 & 0.03 & 0.03 \\
\hline
\end{tabular}

${ }^{* * *} p<0.01,{ }^{* *} p<0.05,{ }^{*} p<0.1$

The random-intercept models account for all individual-level predictors from Table 1, but the coefficients are not shown. Standard errors in the parentheses.

The dependent variable varies from one (least xenophobic) to five (most xenophobic).

\section{A Appendix}

Table A1: Descriptive statistics

\begin{tabular}{lcccc} 
& $\mathrm{n}$ & $\%$ & Weighted $\%$ & Census data (2010, \%) \\
\hline Individual-level predictors & & & & \\
\hline Gender & & & & 54 \\
Female & 13535 & 55 & 55 & 46 \\
Male & 10965 & 45 & 45 & 45.4 \\
Age (mean); census: aged over 18 & 24500 & 44.5 & 44.5 & 35 \\
Education; census: aged over 15 & & & & 6 \\
Secondary or less & 7814 & 32 & 30 & 31 \\
Lower vocational & 1878 & 8 & 7 & 5 \\
Secondary specialized & 9956 & 41 & 40 & 23 \\
Higher incomplete & 663 & 3 & 3 & 78 \\
Higher or PhD & 4157 & 17 & 20 & 2.1 \\
Ethnicity & & & & 0.4 \\
Russian & 21211 & 87 & 86 & 1.4 \\
Bashkir/Chuvash & 581 & 2 & 2 & 0.5 \\
Belorussian & 113 & $<1$ & $<1$ & 0.4 \\
Georgian/Armenian/Azerbaijani & 205 & $<1$ & 1 & 1.3 \\
Kazakh & 166 & $<1$ & $<1$ & 4.7 \\
Kyrgyz/Tajik/Uzbek & 65 & $<1$ & $<1$ & 3.7 \\
Mari/Mordva/Udmurt & 468 & 2 & 1 & 1.3 \\
from North Caucasus & 82 & $<1$ & $<1$ & 2.7 \\
Tatar & 765 & 3 & 4 & 2 \\
Ukrainian & 375 & 2 & 2 & \\
Other & 388 & 2 & 2 & \\
\hline
\end{tabular}




\begin{tabular}{|c|c|c|c|c|}
\hline No data & 81 & $<1$ & $<1$ & 3.5 \\
\hline \multicolumn{5}{|l|}{ Employment status / occupation } \\
\hline Manual & 5985 & 24 & 23 & \\
\hline Non-manual & 7846 & 32 & 35 & \\
\hline Not working and not looking for a job & 928 & 4 & 4 & \\
\hline Retired & 6316 & 26 & 25 & \\
\hline Student & 1140 & 5 & 5 & \\
\hline Unemployed & 1461 & 6 & 6 & \\
\hline Other or no answer & 824 & 3 & 3 & \\
\hline \multicolumn{5}{|l|}{ Monthly personal income (rubles) } \\
\hline$<8,000$ & 7249 & 30 & 25 & \\
\hline $8,000-15,000$ & 8099 & 33 & 32 & \\
\hline $15,000-30,000$ & 3447 & 14 & 17 & \\
\hline$>30,000$ & 517 & 2 & 4 & \\
\hline No income & 2297 & 9 & 10 & \\
\hline No answer & 2891 & 12 & 13 & \\
\hline \multicolumn{5}{|l|}{ Religious denomination } \\
\hline Orthodox Christian & 18669 & 76 & 76 & \\
\hline Buddhist & 25 & $<1$ & $<1$ & \\
\hline Judaist & 13 & $<1$ & $<1$ & \\
\hline Muslim & 951 & 4 & 5 & \\
\hline Other Christian & 271 & 1 & 1 & \\
\hline Not religious & 4046 & 17 & 16 & \\
\hline No answer & 534 & 2 & 2 & \\
\hline \multicolumn{5}{|l|}{ Location } \\
\hline City (> 1 million) & 2584 & 11 & 25 & 20 \\
\hline Small city (100,000 to 1 million) & 8405 & 34 & 28 & 29 \\
\hline Town $(<100,000)$ & 6611 & 27 & 23 & 25 \\
\hline Countryside & 6900 & 28 & 24 & 26 \\
\hline \multicolumn{5}{|l|}{ Migration status } \\
\hline Always lived there & 14021 & 57 & 58 & \\
\hline Moved more than 10 yrs ago & 8196 & 33 & 32 & \\
\hline Moved less than 10 yrs ago & 2177 & 9 & 9 & \\
\hline No answer & 106 & $<1$ & $<1$ & \\
\hline \multicolumn{5}{|l|}{ Ever hired an immigrant } \\
\hline Yes & 1864 & 8 & 11 & \\
\hline No or no answer & 22636 & 92 & 89 & \\
\hline
\end{tabular}

"What would have been your attitude if an ordinary family from ... had become your neighbours?" (On a five-point scale: 1 most positive, 5 most negative)

\begin{tabular}{lllll}
\hline Ukraine & 23671 & 2.5 & 2.5 & \\
After imputation & 24500 & 2.5 & & \\
Moldova & 23167 & 2.8 & 2.8 & \\
After imputation & 24500 & 2.8 & & \\
Caucasus & 23424 & 3.5 & 3.6 & Continued on next page \\
\hline
\end{tabular}




\begin{tabular}{lcccc}
\hline \multicolumn{1}{c}{ After imputation } & 24500 & 3.5 & & \\
Central Asia & 23343 & 3.6 & 3.7 & \\
$\quad$ After imputation & 24500 & 3.6 & & \\
South-East Asia & 23068 & 3.7 & 3.8 & \\
$\quad$ After imputation & 24500 & 3.7 & & \\
North Caucasus & 22964 & 3.8 & 3.8 & \\
$\quad$ After imputation & 24500 & 3.8 & & max \\
Composite index & 21390 & 3.3 & 3.4 & 6.1 \\
$\quad$ After imputation & 24500 & 3.3 & & 42 \\
\hline Regional-level predictors & $\mathrm{n}$ & mean & $\min$ & 97 \\
\hline Average income-to-subsistence ratio & 49 & 3.4 & 2.5 & 4.1 \\
\% unemployed & 49 & 6.6 & 1.4 & 0.34 \\
\% with higher education & 49 & 21 & 15 & \\
\% ethnic Russian & 49 & 86 & 27 & 0.1 \\
\% immigrants & 49 & 1.1 & 0.01 & \\
n of international money transfers & 49 & 0.06 & & \\
per person & & & & \\
\hline \hline
\end{tabular}


Table A2: Individual-level predictors of xenophobic attitudes (by region of origin of immigrants)

\begin{tabular}{|c|c|c|c|c|c|c|}
\hline & Ukraine & Moldova & Caucasus & $\begin{array}{c}\text { North } \\
\text { Caucasus }\end{array}$ & $\begin{array}{c}\text { Central } \\
\text { Asia }\end{array}$ & $\begin{array}{c}\text { South-East } \\
\text { Asia }\end{array}$ \\
\hline Intercept & $\begin{array}{l}2.8^{* * *} \\
(0.05)\end{array}$ & $\begin{array}{l}3.1^{* * *} \\
(0.05)\end{array}$ & $\begin{array}{l}3.9^{* * *} \\
(0.05)\end{array}$ & $\begin{array}{l}4.1^{* * *} \\
(0.05)\end{array}$ & $\begin{array}{l}4.0^{* * *} \\
(0.05)\end{array}$ & $\begin{array}{l}4.0^{* * *} \\
(0.05)\end{array}$ \\
\hline Male & $\begin{array}{l}0.03^{*} \\
(0.02)\end{array}$ & $\begin{array}{l}0.04^{* *} \\
(0.02)\end{array}$ & $\begin{array}{c}0.01 \\
(0.02)\end{array}$ & $\begin{array}{l}-0.02 \\
(0.02)\end{array}$ & $\begin{array}{l}-0.02 \\
(0.02)\end{array}$ & $\begin{array}{l}-0.01 \\
(0.02)\end{array}$ \\
\hline Age (centred around the mean) & $\begin{array}{c}-0.002^{* * *} \\
(0.001)\end{array}$ & $\begin{array}{c}-0.002^{* * *} \\
(0.001)\end{array}$ & $\begin{array}{c}-0.002^{* * *} \\
(0.001)\end{array}$ & $\begin{array}{c}-0.002^{* * *} \\
(0.001)\end{array}$ & $\begin{array}{c}-0.002^{* * *} \\
(0.001)\end{array}$ & $\begin{array}{c}<-0.001 \\
(0.001)\end{array}$ \\
\hline \multicolumn{7}{|l|}{ Education (ref. Secondary or less) } \\
\hline Lower vocational & $\begin{array}{l}-0.02 \\
(0.03)\end{array}$ & $\begin{array}{c}0.02 \\
(0.03)\end{array}$ & $\begin{array}{l}0.08^{* *} \\
(0.03)\end{array}$ & $\begin{array}{c}0.10^{* * *} \\
(0.03)\end{array}$ & $\begin{array}{l}0.07^{* *} \\
(0.03)\end{array}$ & $\begin{array}{c}0.10^{* * *} \\
(0.03)\end{array}$ \\
\hline Secondary specialised & $\begin{array}{c}-0.07^{* * *} \\
(0.02)\end{array}$ & $\begin{array}{c}-0.06^{* * *} \\
(0.02)\end{array}$ & $\begin{array}{c}-0.04^{*} \\
(0.02)\end{array}$ & $\begin{array}{l}<0.01 \\
(0.02)\end{array}$ & $\begin{array}{l}-0.03 \\
(0.02)\end{array}$ & $\begin{array}{l}-0.02 \\
(0.02)\end{array}$ \\
\hline Higher incomplete & $\begin{array}{c}-0.08^{*} \\
(0.05)\end{array}$ & $\begin{array}{c}-0.09^{*} \\
(0.05)\end{array}$ & $\begin{array}{l}-0.06 \\
(0.05)\end{array}$ & $\begin{array}{l}-0.06 \\
(0.05)\end{array}$ & $\begin{array}{l}-0.06 \\
(0.05)\end{array}$ & $\begin{array}{c}-0.12^{* *} \\
(0.05)\end{array}$ \\
\hline Higher or $\mathrm{PhD}$ & $\begin{array}{c}-0.15^{* * *} \\
(0.02)\end{array}$ & $\begin{array}{c}-0.12^{* * *} \\
(0.02)\end{array}$ & $\begin{array}{c}-0.10^{* * *} \\
(0.03)\end{array}$ & $\begin{array}{c}-0.09^{* * *} \\
(0.03)\end{array}$ & $\begin{array}{c}-0.13^{* * *} \\
(0.03)\end{array}$ & $\begin{array}{c}-0.11^{* * *} \\
(0.03)\end{array}$ \\
\hline \multicolumn{7}{|l|}{ Ethnicity (ref. Russian) } \\
\hline Bashkir/Chuvash & $\begin{array}{c}0.18^{* * *} \\
(0.06)\end{array}$ & $\begin{array}{l}0.14^{* *} \\
(0.06)\end{array}$ & $\begin{array}{c}0.18^{* * *} \\
(0.07)\end{array}$ & $\begin{array}{l}0.12^{*} \\
(0.07)\end{array}$ & $\begin{array}{l}0.16^{* *} \\
(0.06)\end{array}$ & $\begin{array}{c}0.20^{* * *} \\
(0.06)\end{array}$ \\
\hline Belorussian & $\begin{array}{c}-0.27^{* *} \\
(0.11)\end{array}$ & $\begin{array}{c}-0.27^{* *} \\
(0.11)\end{array}$ & $\begin{array}{l}-0.15 \\
(0.11)\end{array}$ & $\begin{array}{c}-0.21^{*} \\
(0.11)\end{array}$ & $\begin{array}{c}-0.18^{*} \\
(0.11)\end{array}$ & $\begin{array}{c}-0.28^{* *} \\
(0.11)\end{array}$ \\
\hline Georgian/Armenian/Azerbaijani & $\begin{array}{c}-0.46^{* * *} \\
(0.08)\end{array}$ & $\begin{array}{c}-0.63^{* * *} \\
(0.08)\end{array}$ & $\begin{array}{c}-1.28^{* * *} \\
(0.08)\end{array}$ & $\begin{array}{c}-1.16^{* * *} \\
(0.09)\end{array}$ & $\begin{array}{c}-0.92^{* * *} \\
(0.08)\end{array}$ & $\begin{array}{c}-0.80^{* * *} \\
(0.09)\end{array}$ \\
\hline Kazakh & $\begin{array}{c}-0.01 \\
(0.1)\end{array}$ & $\begin{array}{l}-0.17 \\
(0.11)\end{array}$ & $\begin{array}{c}-0.19^{*} \\
(0.11)\end{array}$ & $\begin{array}{c}-0.20^{*} \\
(0.11)\end{array}$ & $\begin{array}{c}-0.35^{* * *} \\
(0.11)\end{array}$ & $\begin{array}{l}-0.10 \\
(0.11)\end{array}$ \\
\hline Kyrgyz/Tajik/Uzbek & $\begin{array}{c}-0.62^{* * *} \\
(0.14)\end{array}$ & $\begin{array}{c}-0.61^{* * *} \\
(0.15)\end{array}$ & $\begin{array}{c}-0.99^{* * *} \\
(0.15)\end{array}$ & $\begin{array}{c}-1.08^{* * *} \\
(0.15)\end{array}$ & $\begin{array}{c}-1.15^{* * *} \\
(0.15)\end{array}$ & $\begin{array}{c}-0.92^{* * *} \\
(0.15)\end{array}$ \\
\hline Mari/Mordva/Udmurt & $\begin{array}{c}0.25^{* * *} \\
(0.06)\end{array}$ & $\begin{array}{c}0.19^{* * *} \\
(0.06)\end{array}$ & $\begin{array}{c}0.10 \\
(0.06)\end{array}$ & $\begin{array}{c}0.09 \\
(0.06)\end{array}$ & $\begin{array}{l}0.12^{*} \\
(0.06)\end{array}$ & $\begin{array}{c}0.17^{* * *} \\
(0.06)\end{array}$ \\
\hline from North Caucasus & $\begin{array}{c}-0.22^{*} \\
(0.13)\end{array}$ & $\begin{array}{c}-0.38^{* * *} \\
(0.13)\end{array}$ & $\begin{array}{c}-0.51^{* * *} \\
(0.14)\end{array}$ & $\begin{array}{c}-0.79^{* * *} \\
(0.14)\end{array}$ & $\begin{array}{c}-0.31^{* *} \\
(0.14)\end{array}$ & $\begin{array}{c}-0.24^{*} \\
(0.14)\end{array}$ \\
\hline Tatar & $\begin{array}{l}-0.02 \\
(0.06)\end{array}$ & $\begin{array}{l}-0.03 \\
(0.06)\end{array}$ & $\begin{array}{l}-0.10 \\
(0.07)\end{array}$ & $\begin{array}{l}-0.06 \\
(0.07)\end{array}$ & $\begin{array}{l}-0.10 \\
(0.06)\end{array}$ & $\begin{array}{l}-0.04 \\
(0.07)\end{array}$ \\
\hline Ukrainian & $\begin{array}{c}-0.57^{* * *} \\
(0.06)\end{array}$ & $\begin{array}{c}-0.43^{* * *} \\
(0.06)\end{array}$ & $\begin{array}{c}-0.16^{* * *} \\
(0.06)\end{array}$ & $\begin{array}{c}-0.16^{* * *} \\
(0.06)\end{array}$ & $\begin{array}{c}-0.12^{* *} \\
(0.06)\end{array}$ & $\begin{array}{l}-0.09 \\
(0.06)\end{array}$ \\
\hline Other & $\begin{array}{c}-0.18^{* * *} \\
(0.06)\end{array}$ & $\begin{array}{c}-0.18^{* * *} \\
(0.06)\end{array}$ & $\begin{array}{c}-0.24^{* * *} \\
(0.06)\end{array}$ & $\begin{array}{c}-0.23^{* * *} \\
(0.06)\end{array}$ & $\begin{array}{c}-0.30^{* * *} \\
(0.06)\end{array}$ & $\begin{array}{c}-0.17^{* * *} \\
(0.06)\end{array}$ \\
\hline No data & $\begin{array}{c}0.08 \\
(0.13)\end{array}$ & $\begin{array}{l}<0.01 \\
(0.14)\end{array}$ & $\begin{array}{l}-0.17 \\
(0.15)\end{array}$ & $\begin{array}{l}-0.22 \\
(0.14)\end{array}$ & $\begin{array}{l}-0.22 \\
(0.15)\end{array}$ & $\begin{array}{l}-0.11 \\
(0.16)\end{array}$ \\
\hline \multicolumn{7}{|l|}{$\begin{array}{l}\text { Employment status / occupation } \\
\text { (ref. Manual) }\end{array}$} \\
\hline Non-manual & $\begin{array}{c}-0.05^{* * *} \\
(0.02) \\
\end{array}$ & $\begin{array}{c}-0.05^{* *} \\
(0.02) \\
\end{array}$ & $\begin{array}{c}-0.09^{* * *} \\
(0.02)\end{array}$ & $\begin{array}{c}-0.09^{* * *} \\
(0.02)\end{array}$ & $\begin{array}{c}-0.09^{* * *} \\
(0.02)\end{array}$ & $\begin{array}{c}-0.09^{* * *} \\
(0.02)\end{array}$ \\
\hline
\end{tabular}


Table A2 - continued from previous page

\begin{tabular}{|c|c|c|c|c|c|c|}
\hline & Ukraine & Moldova & Caucasus & $\begin{array}{c}\text { North } \\
\text { Caucasus }\end{array}$ & $\begin{array}{l}\text { Central } \\
\text { Asia }\end{array}$ & $\begin{array}{l}\text { South-East } \\
\text { Asia }\end{array}$ \\
\hline Unemployed & $\begin{array}{c}0.02 \\
(0.04)\end{array}$ & $\begin{array}{c}0.06 \\
(0.04)\end{array}$ & $\begin{array}{c}0.01 \\
(0.04)\end{array}$ & $\begin{array}{c}0.02 \\
(0.04)\end{array}$ & $\begin{array}{c}0.02 \\
(0.04)\end{array}$ & $\begin{array}{l}-0.01 \\
(0.04)\end{array}$ \\
\hline $\begin{array}{l}\text { Not working and } \\
\text { not looking for a job }\end{array}$ & $\begin{array}{c}0.02 \\
(0.05)\end{array}$ & $\begin{array}{c}0.02 \\
(0.05)\end{array}$ & $\begin{array}{l}-0.01 \\
(0.05)\end{array}$ & $\begin{array}{l}-0.03 \\
(0.05)\end{array}$ & $\begin{array}{l}-0.06 \\
(0.05)\end{array}$ & $\begin{array}{l}-0.06 \\
(0.05)\end{array}$ \\
\hline Retired & $\begin{array}{l}-0.03 \\
(0.03)\end{array}$ & $\begin{array}{l}-0.01 \\
(0.03)\end{array}$ & $\begin{array}{l}-0.01 \\
(0.03)\end{array}$ & $\begin{array}{l}-0.01 \\
(0.03)\end{array}$ & $\begin{array}{c}-0.05^{*} \\
(0.03)\end{array}$ & $\begin{array}{l}-0.03 \\
(0.03)\end{array}$ \\
\hline Student & $\begin{array}{c}-0.13^{* * *} \\
(0.04)\end{array}$ & $\begin{array}{c}-0.12^{* * *} \\
(0.05)\end{array}$ & $\begin{array}{c}-0.10^{* *} \\
(0.05)\end{array}$ & $\begin{array}{l}-0.07 \\
(0.05)\end{array}$ & $\begin{array}{c}-0.08^{*} \\
(0.05)\end{array}$ & $\begin{array}{c}-0.15^{* * *} \\
(0.05)\end{array}$ \\
\hline Other or NA & $\begin{array}{l}-0.03 \\
(0.04)\end{array}$ & $\begin{array}{l}-0.04 \\
(0.04)\end{array}$ & $\begin{array}{l}-0.08^{*} \\
(0.05)\end{array}$ & $\begin{array}{l}-0.05 \\
(0.04)\end{array}$ & $\begin{array}{c}-0.10^{* *} \\
(0.05)\end{array}$ & $\begin{array}{l}-0.1^{* *} \\
(0.05)\end{array}$ \\
\hline \multicolumn{7}{|l|}{ Income (ref. $<8,000$ rub.) } \\
\hline 8,000 to 15,000 rub. & $\begin{array}{l}-0.01 \\
(0.02)\end{array}$ & $\begin{array}{l}-0.01 \\
(0.02)\end{array}$ & $\begin{array}{c}<-0.01 \\
(0.02)\end{array}$ & $\begin{array}{c}<-0.01 \\
(0.02)\end{array}$ & $\begin{array}{c}<-0.01 \\
(0.02)\end{array}$ & $\begin{array}{l}-0.01 \\
(0.02)\end{array}$ \\
\hline 15,000 to 30,000 rub. & $\begin{array}{l}-0.01 \\
(0.03)\end{array}$ & $\begin{array}{c}0.02 \\
(0.03)\end{array}$ & $\begin{array}{c}0.01 \\
(0.03)\end{array}$ & $\begin{array}{c}0.03 \\
(0.03)\end{array}$ & $\begin{array}{c}0.03 \\
(0.03)\end{array}$ & $\begin{array}{c}0.01 \\
(0.03)\end{array}$ \\
\hline$>30,000$ rub. & $\begin{array}{l}-0.07 \\
(0.05)\end{array}$ & $\begin{array}{l}-0.01 \\
(0.06)\end{array}$ & $\begin{array}{l}-0.05 \\
(0.06)\end{array}$ & $\begin{array}{l}-0.07 \\
(0.06)\end{array}$ & $\begin{array}{l}-0.05 \\
(0.06)\end{array}$ & $\begin{array}{l}-0.09 \\
(0.06)\end{array}$ \\
\hline No income & $\begin{array}{l}0.06^{*} \\
(0.03)\end{array}$ & $\begin{array}{l}0.06^{*} \\
(0.04)\end{array}$ & $\begin{array}{c}0.04 \\
(0.04)\end{array}$ & $\begin{array}{c}0.02 \\
(0.04)\end{array}$ & $\begin{array}{l}0.07^{*} \\
(0.04)\end{array}$ & $\begin{array}{l}0.08^{* *} \\
(0.03)\end{array}$ \\
\hline No answer & $\begin{array}{l}0.13^{* * *} \\
(0.03)\end{array}$ & $\begin{array}{c}0.11^{* * *} \\
(0.03)\end{array}$ & $\begin{array}{c}0.04 \\
(0.03)\end{array}$ & $\begin{array}{c}0.03 \\
(0.03)\end{array}$ & $\begin{array}{l}0.08^{* * *} \\
(0.03)\end{array}$ & $\begin{array}{c}0.04 \\
(0.03)\end{array}$ \\
\hline \multicolumn{7}{|l|}{ Religion (ref. Orthodox Christian) } \\
\hline Buddhist & $\begin{array}{c}-0.45^{* *} \\
(0.23)\end{array}$ & $\begin{array}{c}-0.57^{* *} \\
(0.24)\end{array}$ & $\begin{array}{c}-0.48^{* *} \\
(0.24)\end{array}$ & $\begin{array}{c}-0.68^{* * *} \\
(0.24)\end{array}$ & $\begin{array}{c}-0.49^{*} \\
(0.26)\end{array}$ & $\begin{array}{c}-0.57^{* *} \\
(0.24)\end{array}$ \\
\hline Judaist & $\begin{array}{l}-0.23 \\
(0.30)\end{array}$ & $\begin{array}{l}-0.38 \\
(0.32)\end{array}$ & $\begin{array}{c}-0.79^{* *} \\
(0.33)\end{array}$ & $\begin{array}{c}-1.11^{* * *} \\
(0.32)\end{array}$ & $\begin{array}{c}-0.82^{* *} \\
(0.32)\end{array}$ & $\begin{array}{c}-0.67^{* *} \\
(0.32)\end{array}$ \\
\hline Muslim & $\begin{array}{l}0.11^{*} \\
(0.06)\end{array}$ & $\begin{array}{c}0.02 \\
(0.06)\end{array}$ & $\begin{array}{l}-0.11^{*} \\
(0.06)\end{array}$ & $\begin{array}{c}-0.15^{* *} \\
(0.07)\end{array}$ & $\begin{array}{c}-0.16^{* *} \\
(0.06)\end{array}$ & $\begin{array}{l}-0.12^{*} \\
(0.06)\end{array}$ \\
\hline Not religious & $\begin{array}{l}0.06^{* * *} \\
(0.02)\end{array}$ & $\begin{array}{l}0.04^{*} \\
(0.02)\end{array}$ & $\begin{array}{l}-0.01 \\
(0.02)\end{array}$ & $\begin{array}{c}-0.05^{* *} \\
(0.02)\end{array}$ & $\begin{array}{l}-0.03 \\
(0.02)\end{array}$ & $\begin{array}{c}-0.05^{* *} \\
(0.02)\end{array}$ \\
\hline Other Christian & $\begin{array}{c}-0.16^{* *} \\
(0.07)\end{array}$ & $\begin{array}{c}-0.24^{* * *} \\
(0.07)\end{array}$ & $\begin{array}{c}-0.33^{* * *} \\
(0.07)\end{array}$ & $\begin{array}{c}-0.25^{* * *} \\
(0.07)\end{array}$ & $\begin{array}{c}-0.30^{* * *} \\
(0.08)\end{array}$ & $\begin{array}{c}-0.32^{* * *} \\
(0.07)\end{array}$ \\
\hline No answer & $\begin{array}{c}0.15^{* * *} \\
(0.05)\end{array}$ & $\begin{array}{c}0.03 \\
(0.06)\end{array}$ & $\begin{array}{l}-0.07 \\
(0.06)\end{array}$ & $\begin{array}{l}-0.12 \\
(0.06)\end{array}$ & $\begin{array}{c}-0.14^{* * *} \\
(0.05)\end{array}$ & $\begin{array}{c}-0.10^{*} \\
(0.05)\end{array}$ \\
\hline \multicolumn{7}{|l|}{ Location (ref. City $>1$ million) } \\
\hline Small city (100,000 to 1 million) & $\begin{array}{c}-0.13^{* * *} \\
(0.04)\end{array}$ & $\begin{array}{c}-0.17^{* * *} \\
(0.04)\end{array}$ & $\begin{array}{c}-0.21^{* * *} \\
(0.04)\end{array}$ & $\begin{array}{c}-0.15^{* * *} \\
(0.04)\end{array}$ & $\begin{array}{c}-0.15^{* * *} \\
(0.04)\end{array}$ & $\begin{array}{c}-0.12^{* * *} \\
(0.04)\end{array}$ \\
\hline Town $(<100,000)$ & $\begin{array}{c}-0.22^{* * *} \\
(0.04)\end{array}$ & $\begin{array}{c}-0.24^{* * *} \\
(0.04)\end{array}$ & $\begin{array}{c}-0.22^{* * *} \\
(0.04)\end{array}$ & $\begin{array}{c}-0.17^{* * *} \\
(0.04)\end{array}$ & $\begin{array}{c}-0.19^{* * *} \\
(0.04)\end{array}$ & $\begin{array}{c}-0.11^{* * *} \\
(0.04)\end{array}$ \\
\hline Countryside & $\begin{array}{c}-0.21^{* * *} \\
(0.04)\end{array}$ & $\begin{array}{c}-0.27^{* * *} \\
(0.04)\end{array}$ & $\begin{array}{c}-0.27^{* * *} \\
(0.04)\end{array}$ & $\begin{array}{c}-0.22^{* * *} \\
(0.04)\end{array}$ & $\begin{array}{c}-0.26^{* * *} \\
(0.04)\end{array}$ & $\begin{array}{c}-0.13^{* * *} \\
(0.04)\end{array}$ \\
\hline \multicolumn{7}{|l|}{$\begin{array}{l}\text { Migration status } \\
\text { (ref.: Always lived there) }\end{array}$} \\
\hline Moved more than 10 years ago & $-0.08^{* * *}$ & $-0.09^{* * *}$ & $-0.07^{* * *}$ & $-0.06^{* * *}$ & $-0.10^{* * *}$ & $-0.08^{* * *}$ \\
\hline
\end{tabular}


Table A2 - continued from previous page

\begin{tabular}{lcccccc}
\hline & Ukraine & Moldova & Caucasus & North & Central & South-East \\
& & & & Caucasus & Asia & Asia \\
\hline \multirow{2}{*}{ Moved less than 10 years ago } & $(0.02)$ & $(0.02)$ & $(0.02)$ & $(0.02)$ & $(0.02)$ & $(0.02)$ \\
& $-0.13^{* * *}$ & $-0.13^{* * *}$ & $-0.14^{* * *}$ & $-0.12^{* * *}$ & $-0.17^{* * *}$ & $-0.17^{* * *}$ \\
No answer & $(0.03)$ & $(0.03)$ & $(0.03)$ & $(0.03)$ & $(0.03)$ & $(0.03)$ \\
& -0.04 & 0.05 & 0.13 & 0.04 & 0.11 & 0.05 \\
Hired an immigrant & $(0.11)$ & $(0.13)$ & $(0.13)$ & $(0.12)$ & $(0.13)$ & $(0.13)$ \\
(ref.: Did not hire) & $-0.11^{* * *}$ & $-0.14^{* * *}$ & $-0.18^{* * *}$ & $-0.16^{* * *}$ & $-0.21^{* * *}$ & $-0.12^{* * *}$ \\
\hline No obs. & $(0.03)$ & $(0.03)$ & $(0.03)$ & $(0.03)$ & $(0.03)$ & $(0.03)$ \\
No regions & 24500 & 24500 & 24500 & 24500 & 24500 & 24500 \\
Variance: intercept & 49 & 49 & 49 & 49 & 49 & 49 \\
Variance: residual & 0.03 & 0.02 & 0.03 & 0.03 & 0.03 & 0.03 \\
\hline
\end{tabular}

${ }^{* * *} p<0.01,{ }^{* *} p<0.05,{ }^{*} p<0.1$

The random intercept model. The dependent variables vary from one

(least xenophobic) to five (most xenophobic).

Table A3: Models with the alternative measure of immigrant concentration

Model $1 \quad$ Model $2 \quad$ Model 3

\begin{tabular}{lcccccc} 
& coef. & s.e. & coef. & s.e. & coef. & s.e. \\
\hline Constant & $3.6^{* * *}$ & $(0.05)$ & $3.9^{* * *}$ & $(0.12)$ & $3.7^{* * *}$ & $(0.15)$ \\
international money transfers & $0.95^{* * *}$ & $(0.28)$ & $0.92^{* * *}$ & $(0.38)$ & $0.82^{* * *}$ & $(0.33)$ \\
income-to-subsistence ratio & & & $-0.08^{* * *}$ & $(0.03)$ & $-0.08^{* * *}$ & $(0.03)$ \\
Moscow & & & 0.27 & $(0.18)$ & 0.28 & $(0.17)$ \\
\% ethnically Russian & & & & & $\approx 0.01$ & $(\approx 0.01)$ \\
\hline n obs. & 24500 & & 24500 & & 24500 & \\
n regions & 49 & & 49 & & 49 & \\
\hline
\end{tabular}

${ }^{* * *} p<0.01,{ }^{* *} p<0.05,{ }^{*} p<0.1$

The random-intercept models account for all individual-level predictors from Table 1, but the coefficients are not shown.

The dependent variable varies from one (least xenophobic) to five (most xenophobic). 
Table A4: Models with the alternative measure of immigrant concentration by region of immigration

\begin{tabular}{lcccccc} 
& Ukraine & Moldova & Caucasus & Central Asia & South-East Asia & North Caucasus \\
\hline Constant & $3.0^{* * *}$ & $3.4^{* * *}$ & $4.1^{* * *}$ & $4.2^{* * *}$ & $4.2^{* * *}$ & $4.3^{* * *}$ \\
& $(0.16)$ & $(0.14)$ & $(0.16)$ & $(0.17)$ & $(0.17)$ & $(0.17)$ \\
international money & 0.23 & $0.98^{* * *}$ & $1.00^{* *}$ & $1.13^{* *}$ & $1.17^{* *}$ & $0.92^{* *}$ \\
transfers & $(0.45)$ & $(0.37)$ & $(0.43)$ & $(0.46)$ & $(0.45)$ & $(0.46)$ \\
income ratio & -0.07 & $-0.08^{* *}$ & $-0.08^{*}$ & $-0.09^{*}$ & $-0.09^{* *}$ & $-0.09^{*}$ \\
& $(0.05)$ & $(0.04)$ & $(0.04)$ & $(0.05)$ & $(0.05)$ & $(0.05)$ \\
Moscow & 0.39 & 0.14 & 0.21 & 0.26 & 0.28 & 0.32 \\
& $(0.25)$ & $(0.20)$ & $(0.23)$ & $(0.25)$ & $(0.24)$ & $(0.25)$ \\
\hline n obs. & 24500 & 24500 & 24500 & 24500 & 24500 & 24500 \\
n regions & 49 & 49 & 49 & 49 & 49 & 49 \\
\hline
\end{tabular}

${ }^{* * *} p<0.01,{ }^{* *} p<0.05,{ }^{*} p<0.1$

The random-intercept models account for all individual-level predictors from Table 1, but the coefficients are not shown. Standard errors in the parentheses.

The dependent variable varies from one (least xenophobic) to five (most xenophobic). 